\title{
NEW TAXA OF LORICATE EUGLENOIDS STROMBOMONAS AND TRACHELOMONAS FROM THAILAND
}

\author{
KRITSANA DUANGJAN \& KONRAD WOŁOWSKI*
}

\begin{abstract}
Five new species and one new variety of loricate euglenoid taxa were discovered in Thailand: Strombomonas starmachii Duangjan \& Wołowski, S. chiangmaiensis Duangjan, Trachelomonas peerapornpisalii Duangjan \& Wołowski, T. thailandicus Duangjan \& Wołowski, T. reticulato-spinifera Duangjan and T. hystrix var. paucispinosa Prowse. We propose to raise the variety to species level [T. paucispinosa (Prowse) Duangjan \& Wołowski, stat. et comb. nov.]. The morphology and fine lorica ultrastructure of the species are described. All taxa are documented by SEM images and some by LM micrographs.
\end{abstract}

Key words: Thailand, Euglenophyta, Strombomonas, Trachelomonas, new taxa

Kritsana Duangjan, Microbiology Section, Department of Biology, Faculty of Science, Chiang Mai University, Chiang Mai, Thailand; e-mail:vvb_hunter@hotmail.com

Konrad Wołowski, Phycological Department, W. Szafer Institute of Botany, Polish Academy of Sciences, Lubicz 46, $31-512$ Kraków, Poland; e-mail:k.wolowski@botany.pl

\section{INTRODUCTION}

The lorica is a protective envelope surrounding the protoplast in some euglenoid genera such as Strombomonas, Trachelomonas and Ascoglena. The mature individual has its own taxon-specific lorica. Lorica characters can facilitate identification but the lorica also frequently obscures the cell (monad) inside it, and the range of intraspecific variation of its morphology needs to be determined in clonal culture. Nor can cytological and genetic studies be assured of clear results when only a small sample is available. So far the lorica development process is not sufficiently known for the majority of taxa, despite the importance of the morphological characters of mature loricas for identifying and describing new loricate euglenoid taxa. According to several researchers (Ciugulea et al. 2008; Brosnan et al. 2005) the identification of Strombomonas and Trachelomonas taxa from field collections alone is nearly impossible, but despite that we believe that the morphological diversity should be recorded. The lack of molecular

\footnotetext{
* Corresponding author
}

data should not exclude morphological descriptions as a valid taxonomical observation.

Some of the first descriptive information about loricate taxa was published by the eminent phycologists Ehrenberg (1833) and Stein (1878), and later by Lemmermann (1913), Playfair (1915), Deflandre (1926, 1930) and Conrad (1932), Popova and Safonova (1976), Starmach (1983). Lorica development was studied and described in cultured Trachelomonas species by Pringsheim (1953), Singh (1956) and Lidale (1975). More recent years have brought detailed studies of lorica ultrastructure (e.g., Conforti 1999; Conforti \& Tell 1986; Conforti \& Perez 2000; Wołowski \& Hindák 2004, 2005; Wołowski \& Walne 2007; Da et al. 2009 and Ciugulea \& Triemer 2010). West et al. (1980), Dunlap et al. (1983), Dunlap \& Walne (1985) and Dunlap et al. (1986) made detailed studies of the element composition and microarchitecture of the lorica in selected Trachelomonas and Strombomonas taxa. Recently, Brosnan et al. (2003, 2005) and Ciugulea et al. (2008) addressed problems related to separation of those genera based on differences in lorica morphology and 
development. Ciugulea et al. (2008), Linton et al. (2010) demonstrated the very high diagnostic value of cell morphology (number of chloroplasts, type of pyrenoid).

Information about the euglenoids of Thailand is scarce. The main sources of information about the group are references given by Lewmanomont et al. (1995) and Peerapornpisal et al. (2004) in publications on different taxonomic groups of algae. Yamagishi (2010) published information, with good documentation, about 31 Trachelomonas and 7 Strombomonas euglenophyte species occurring in Thai ponds. Recently, Duangjan et al. (2012) gave descriptions accompanied by LM and SEM documentation for 49 taxa of Trachelomonas.

This paper presents the results of a study on euglenoids from various small water bodies in northern Thailand. Most parts of the country are under tropical wet and dry climate.

\section{MATERIALS AND METHODS}

Each month from April 2009 to March 2010, samples were collected from different types of ponds in northern Thailand. The material was taken from open water with a plankton net (10 $\mu \mathrm{m}$ mesh) and from the bottom with a slime aspirator, and then placed in plastic flasks ( $\mathrm{ca}$ $100 \mathrm{ml}$ ) and divided into two parts: one preserved with Lugol's solution, and the other transported as fresh material and studied in the laboratory with an Olympus CX31 light microscope.

Taxonomic studies were based on live and preserved material observed by LM with an Olympus BX51 and a Nikon Eclipse E600 with Nomarski phase contrast. For SEM, samples were prepared according to the procedures described by Bozzola \& Russell (1991) and then studied with a Hitachi S-4700 SEM in the Scanning Microscopy Laboratory of Biological and Geological Sciences, Jagiellonian University, Kraków, Poland.

Water $\mathrm{pH}$ and conductivity were determined with a pH/ORP electrode SMS125. Alkalinity was measured by the phenolphthalein methyl orange indicator method (Greenberg et al. 2005). Nutrient concentrations $\left(\mathrm{PO}_{4}\right.$, $\mathrm{NO}_{3}, \mathrm{NH}_{4}$ ) were measured in the laboratory: nitrate nitrogen analysis by cadmium reduction method, am- monium nitrogen analysis by Nesslerization method, soluble reactive phosphorus (SRP) by ascorbic acid method (Greenberg et al. 2005).

\section{RESULTS}

All descriptions are based on phenotype observations of living specimens by LM. Detailed observations of lorica structure were made by SEM. The new taxa described below were found in a fishpond and a garden pond. Samples were collected from the pond bottom or as plankton and in some cases scraped from plant parts.

Strombomonas starmachii Duangjan \& Wołowski, sp. nov.

Figs 1-5

Lorica irregularly oval, 19.2-22.5 $\mu \mathrm{m}$ wide, 29.8-30.9 $\mu \mathrm{m}$ long, collar very low, extensive, surrounding apical pore $(1.7 \times 1.2 \mu \mathrm{m})$ located at top of diagonally truncated tube $3 \mu \mathrm{m}$ high moved to right side of rim, wall irregular, scrobiculate, covered by small sand grains. Cell ovoid, chloroplasts numerous, disc-shaped with pyrenoids, paramylon bodies small, cylindrical or ellipsoidal. Species similar to $S$. amphoraeformis (Hortobagy) Huber-Pestalozzi (1955) in general view and lorica structure, but our specimens have a characteristic well developed collar; the shape of the lorica also resembles that of monads of some Urceolus taxa (U. cyclostomus or U. macromastix) which are colorless euglenoids and have no lorica.

HolOTYPE: slide number 15, deposited in Applied Algal Research Laboratory, Department of Biology, Faculty of Science, Chiang Mai University, Thailand (ICONOTYPE: Fig. 3).

ETYMOLOGY. Named to honor the memory of the eminent phycologist and hydrobiologist Karol Starmach.

Distribution. Found in fishpond, Chiang Rai Province, Cabbages and Condoms (C\&C) Restau$\operatorname{rant}\left(19.26635^{\circ} \mathrm{N}, 99.51508^{\circ} \mathrm{E}\right)$ with the following water parameters: conductivity $191-193 \mu \mathrm{S} \mathrm{cm}^{-1}$;

Figs 1-11. 1-5 - Strombomonas starmachii Duangjan \& Wołowski, sp. nov. 1, 2 \& 4 - live specimens inside lorica by LM, $3 \& 5$ - lorica ultrastructure by SEM; 6-11-S. chiangmaiensis Duangjan, sp. nov. 6-8 - live specimens inside lorica in various positions by LM, 9-11 - lorica ultrastructure in various views by SEM. 

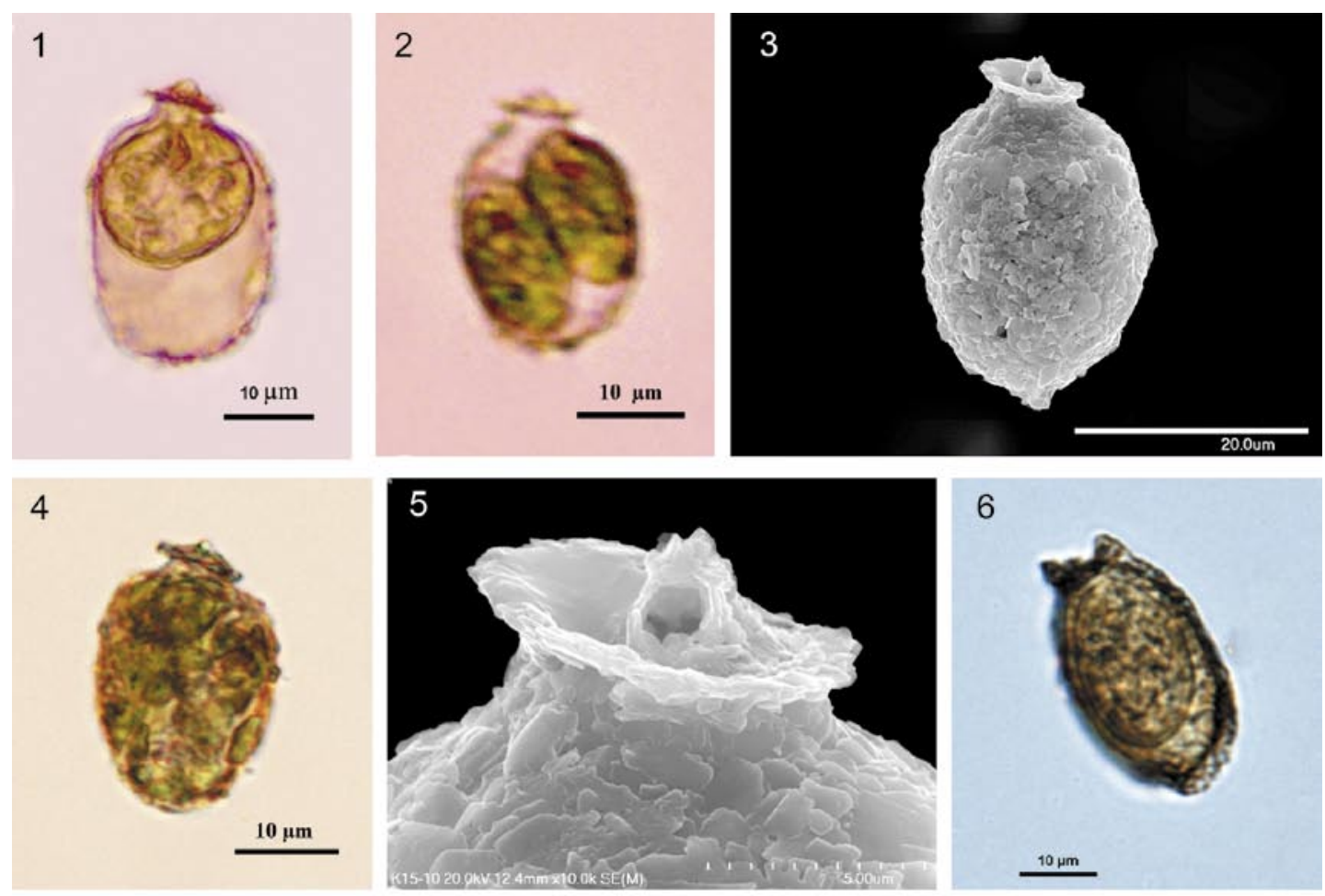

6
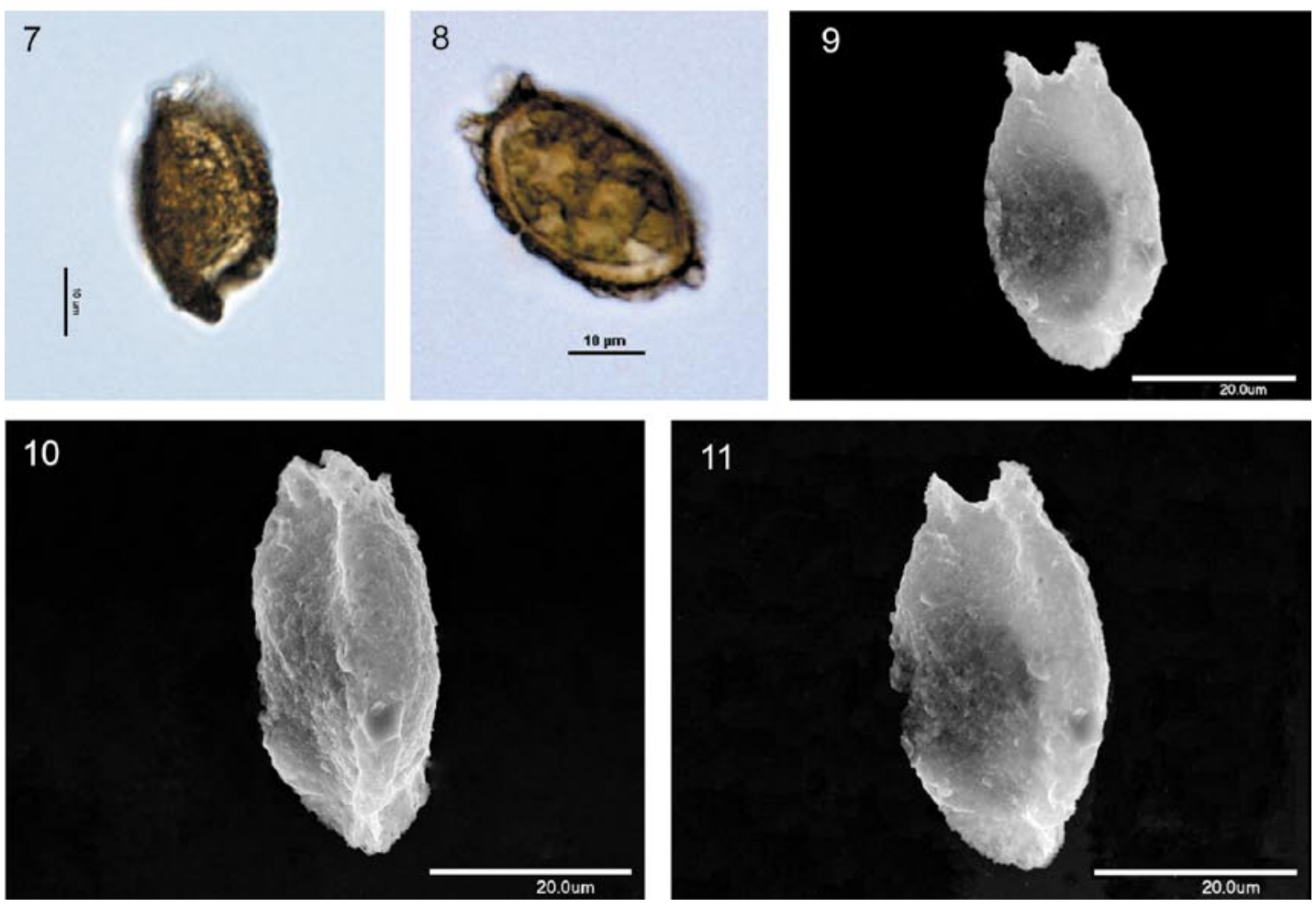
pH 6.75-6.97; alkalinity $60 \mathrm{mg} \mathrm{l}^{-1}$ as $\mathrm{CaCO}_{3}$; $\mathrm{PO}_{4}$ 1.42-1.47 $\mathrm{mg} \mathrm{l}^{-1}$; $\mathrm{NO}_{3} 1.20-2.10 \mathrm{mg} \mathrm{l}^{-1} ; \mathrm{NH}_{4} 5.10$ $5.21 \mathrm{mg} \mathrm{l}^{-1}$. Several specimens were observed.

Strombomonas chiangmaiensis Duangjan, sp. nov.

Figs 6-11

Lorica triple-walled, longitudinally oval in outline, 17.4-26.5 $\mu \mathrm{m}$ wide, 33.3-43.3 $\mu \mathrm{m}$ long, ca $9.7 \mu \mathrm{m}$ thick, no collar, incised at top, posterior part slightly narrowed, ended with fin, wall irregular-scrobiculate, slightly concave on 3 sides, tapered at edges, yellow to brown. Cell obovoid, chloroplasts numerous, disc-shaped with pyrenoids, paramylon bodies small, cylindrical or ellipsoidal. Species similar to S. scabra Tell \& Conforti var. labiata but our specimens were triple-walled, and to $S$. triguetra Playfair 1915 Deflandre 1930 which differs from our specimens by its regular shape and short collar.

HOLOTYPE: slide number 13, deposited in Applied Algal Research Laboratory, Department of Biology, Faculty of Science, Chiang Mai University, Thailand (ICONOTYPE: Fig. 11).

ETYMOLOGY. The epithet chiangmaiensis refers to Chiang Mai, where the material was collected.

Distribution. Found in fishpond, Chiang Rai Province, Cabbages and Condoms (C\&C) Restaurant $(19.26635 \mathrm{~N}, 99.51508 \mathrm{E})$ with the following water parameters: conductivity $120-133 \mu \mathrm{S} \mathrm{cm}^{-1}$; pH 5.6-5.9; alkalinity 45-50 $\mathrm{mg} \mathrm{l}^{-1}$ as $\mathrm{CaCO}_{3} ; \mathrm{PO}_{4}$ $0.71-1.07 \mathrm{mg} \mathrm{l}^{-1} ; \mathrm{NO}_{3} 0.1-1.0 \mathrm{mg} \mathrm{l}^{-1} ; \mathrm{NH}_{4} 1.76$ $\mathrm{mg}^{-1}$. Several specimens were observed.

\section{Trachelomonas peerapornpisalii Duangjan}

\& Wołowski, sp. nov.

Figs 12-19

Lorica broadly ellipsoidal in side view, spherical from top view, wider than longer, 15.3$17.9 \mu \mathrm{m}$ wide, 11.6-12.3 $\mu \mathrm{m}$ long, surrounded by three rings, collar small, apical pore $3.5 \mu \mathrm{m}$ in diameter, surrounded by a thickening, wall densely punctate, 17 punctae in $1 \mu \mathrm{m}^{2}$, yellow to brown. Cell oblong, chloroplasts numerous, disc-shaped with pyrenoids, paramylon bodies small, cylindrical or ellipsoidal. Species similar to
T. peridiniformis Skvortzov (1917) but our specimens are smaller and ellipsoidal in side view. The rings are broader than in $T$. peridiniformis. In shape it also resembles T. olla Conrad (1932), which has two rings.

HolotyPE: slide number 3, deposited in Applied Algal Research Laboratory, Department of Biology, Faculty of Science, Chiang Mai University, Thailand (ICONOTYPE: Fig. 18).

ETymology. Named in honor of Associate Professor Yuwadee Peerapornpisal for her many and varied contributions to world algological research.

DisTRIBUTION. Found in a village pond in Chiang Mai Province, Faculty of Agriculture, Chiang Mai University $\left(18.79233^{\circ} \mathrm{N}, 98.96438^{\circ} \mathrm{E}\right)$, containing several water lilies and having the following water parameters: conductivity $146-151 \mu \mathrm{S} \mathrm{cm}^{-1}$; pH 6.0-6.2; alkalinity 35-59 $\mathrm{mg} \mathrm{l}^{-1}$ as $\mathrm{CaCO}_{3}$; $\mathrm{PO}_{4} 0.07-0.18 \mathrm{mg} \mathrm{l}^{-1} ; \mathrm{NO}_{3} 0.2-0.3 \mathrm{mg} \mathrm{l}{ }^{-1} ; \mathrm{NH}_{4}$ $0.01-0.02 \mathrm{mg} \mathrm{l}^{-1}$. Several specimens were observed.

\section{Trachelomonas thailandicus Duangjan}

\& Wołowski, sp. nov.

Fig. 20

Lorica oblong, ca $14 \mu \mathrm{m}$ wide, $24.2 \mu \mathrm{m}$ long, apical pore surrounded by 8 rods (blunt spines) $3 \mu \mathrm{m}$ long, making at the base a low collar ca $1 \mu \mathrm{m}$ high, wall irregularly punctate, 1 punctum in $1 \mu \mathrm{m}^{2}$, and covered by short sparse rods irregularly dispersed. Monads were not observed.

HolOTYPE: slide number 12, deposited in Applied Algal Research Laboratory, Department of Biology, Faculty of Science, Chiang Mai University, Thailand (ICONOTYPE: Fig. 20).

ETYMOLOGY. The epithet thailandicus refers to Thailand, where the material was collected.

DisTRIBUTION. Found in a village pond in Chaing Rai Province, Pa Ko Dam Tobacco Station $\left(19.78423^{\circ} \mathrm{N}, 99.748045^{\circ} \mathrm{E}\right)$, with the following water parameters: conductivity $95 \mu \mathrm{S} \mathrm{cm} \mathrm{cm}^{-1}$; pH 6.9-7.1; alkalinity 51-53 $\mathrm{mg} \mathrm{l}^{-1}$ as $\mathrm{CaCO}_{3} ; \mathrm{PO}_{4}$ $0.01-0.07 \mathrm{mg} \mathrm{l}^{-1} ; \mathrm{NO}_{3} 0.1-0.4 \mathrm{mg} \mathrm{l}^{-1} ; \mathrm{NH}_{4} 0.7-0.9$ $\mathrm{mg} \mathrm{l}^{-1}$. Only one specimen was observed. 

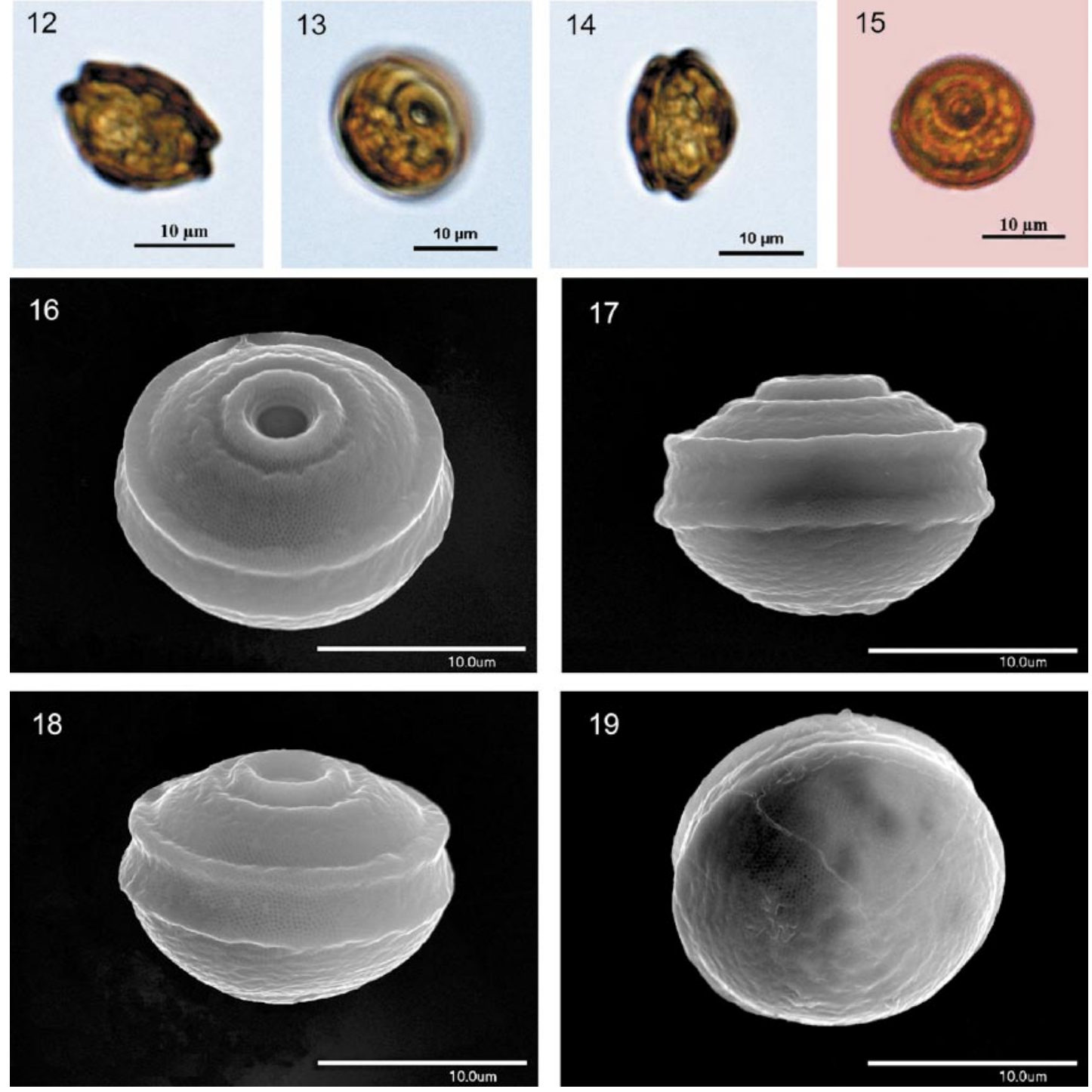

Figs 12-19. Trachelomonas peerapornpisalii Duangjan \& Wołowski, sp. nov. 12-15 - live specimens inside lorica in various positions by LM, 16-19 - lorica ultrastructure in various views by SEM.

Trachelomonas paucispinosa (Prowse) Duangjan \& Wołowski, stat. et comb. nov. Figs $21 \& 22$ BASIONYM: Trachelomonas hystrix Teilings var. paucispinosa Prowse, The Gardens Bulletin Singapore 16: 183, Figs $6 b_{1}, c_{1} .1958$.

Lorica ellipsoidal, 17.1-18.0 $\mu \mathrm{m}$ wide, $25.5-$ $26.8 \mu \mathrm{m}$, collar very low, $1.5 \mu \mathrm{m}$ high with 4 sharp spines $(5.8 \mu \mathrm{m}$ long) well set on the rim, wall punctate, 3 punctae in $2 \mu \mathrm{m}^{2}$, a few spines at both ends, 4.0-8.3 $\mu \mathrm{m}$ long, single short spines covering middle part of lorica, one well developed sharp spine 8.5-9.0 $\mu \mathrm{m}$ long at posterior end. Cell elliptical, chloroplasts numerous, disc-shaped, paramylon bodies small, cylindrical or rod-like.

NoTE: Specimens described by Prowse (1958) as Trachelomonas hystrix var. paucispinosa differ 

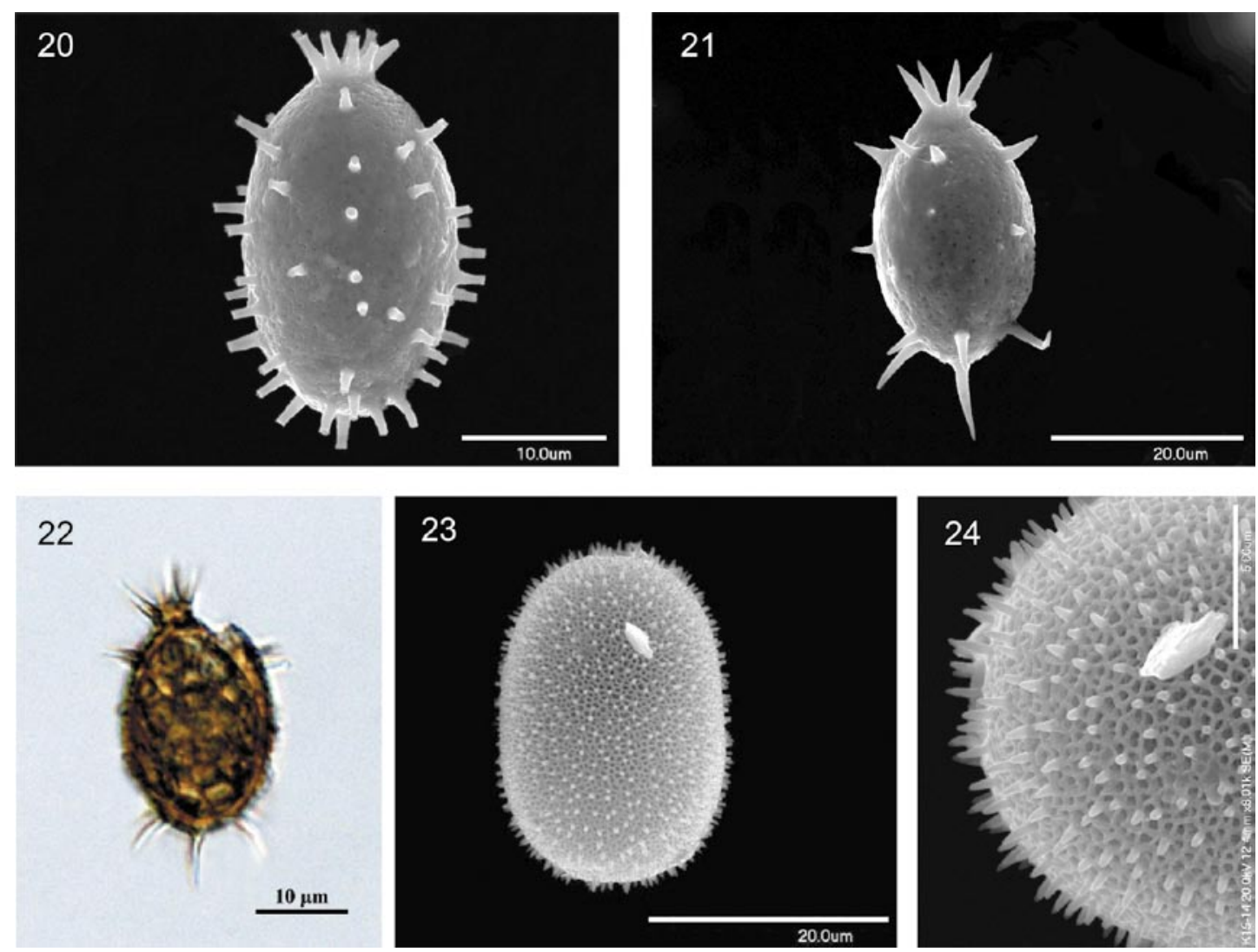

Figs 20-24. 20 - Trachelomonas thailandicus Duangjan \& Wołowski, sp. nov., lorica ultrastructure by SEM; 21, 22 - T. paucispinosa Duangjan \& Wołowski, sp. nov.: 21 - lorica ultrastructure by SEM, 22 - live specimen inside lorica by LM; 23 , 24 - T. reticulato-spinifera Duangjan, sp. nov., detail of lorica ultrastructure by SEM.

from the type taxa $T$. hystrix. The latter is eggshaped to oblong and has a high $(3.0-5.5 \mu \mathrm{m})$, well developed collar with several spines at the rim; the whole lorica is densely punctate, covered by thin spines, and sometimes has one long spine at the posterior end.

Distribution. Found in a village pond in Chaing Rai Province, Pa Ko Dam Tobacco Station $\left(19.78423^{\circ} \mathrm{N}, 99.74804^{\circ} \mathrm{E}\right)$, with the following water parameters: conductivity $95 \mu \mathrm{S} \mathrm{cm}-1$; pH 6.9-7.1; alkalinity $51-53 \mathrm{mg} / \mathrm{l}^{-1}$ as $\mathrm{CaCO}_{3}$; $\mathrm{PO}_{4} 0.01-0.07 \mathrm{mg} \mathrm{l}^{-1} ; \mathrm{NO}_{3} 0.1-0.4 \mathrm{mg} \mathrm{l}^{-1} ; \mathrm{NH}_{4}$ $0.7-0.9 \mathrm{mg} \mathrm{l}^{-1}$. A few specimens were observed. Earlier described from Malaysia as T. hystrix var. paucispinosa by Prowse (1958). Yamagishi (2010) reported it from Malaysia (Alor Setar, ditch) and from Cambodia: Bayon (pond), Preah Ko (paddy field) Baray (paddy field) and Siem Reap (ditch). Conforti and Perez (2000) described it from Uruguay (Rio Negro) as T. mirabilis var. obesa but the picture of the specimen and the description resemble rather Trachelomonas paucispinosa.

\section{Trachelomonas reticulato-spinifera Duangjan,} sp. nov.

Figs $23 \& 24$

Lorica oval, without collar $18.8 \mu \mathrm{m}$ wide, $27.8 \mu \mathrm{m}$ long, round at both ends, apical pore $3 \mu \mathrm{m}$ in diameter, wall reticular, thickly covered with spines (1.0-1.5 $\mu \mathrm{m}$ long), by LM the reticulation resembles pores. Cells were not observed. Species similar to $T$. allia Dreżepolski but our specimens have a reticulated wall and are not punctate. 
HolOtyPE: slide number 15, deposited in Applied Algal Research Laboratory, Department of Biology, Faculty of Science, Chiang Mai University, Thailand (ICONOTYPE: Fig. 23).

ETYMOLOGY. The epithet reticulate-spinifera refers to the lorica ultrastructure.

Distribution. Found in a fishpond in Chiang Rai Province, Cabbages and Condoms (C\&C) Restaurant $\left(19.26635^{\circ} \mathrm{N}, 99.51508^{\circ} \mathrm{E}\right)$, with the following water parameters: conductivity $191-$ $193 \mu \mathrm{S} \mathrm{cm}^{-1}$; pH 6.8-7.0; alkalinity $60 \mathrm{mg} \mathrm{l}^{-1}$ as $\mathrm{CaCO}_{3} ; \mathrm{PO}_{4} 1.42-1.47 \mathrm{mg} \mathrm{l}^{-1} ; \mathrm{NO}_{3} 1.2-2.1$ $\mathrm{mg} \mathrm{l}^{-1} ; \mathrm{NH}_{4} 5.1-5.21 \mathrm{mg} \mathrm{l}^{-1}$. Only one specimen was observed.

\section{DISCUSSION}

The described taxa were among the 136 species of Trachelomonas and 58 of Strombomonas found during long-term study. All of them occurred in shallow polluted ponds.

The two new Strombomonas taxa are described from mature specimens with well formed loricas which are species-specific and identified for the first time. Live cells observed by LM had the same type of lorica as seen in SEM. Several specimens were used for both types of observations, excluding Trachelomonas reticulato-spinifera, only one specimen of which was observed. Surprisingly, the shape of the lorica in Strombomonas starmachii resembles that of monads of the colorless genus Urceolus, which is naked. According to Mereschkowsky (1877) the pellicle of Urecolus sp. has thick spiral striae. Our LM observations indicated (and the micrographs show) two cells after division, which have several chloroplasts, inside the lorica.

One new Trachelomonas species has a smooth lorica. It is similar to T. peridiniformis reported from Europe and Asia, described by Skvortzov (1917), which has three rings, but its lorica is longer than wider ( $22.4 \mu \mathrm{m}$ long, $20.8 \mu \mathrm{m}$ wide). The described taxon is also similar to T. olla described by Conrad (1932) from brackish water in Belgium, but it is larger than T. peerapornpisalii and has only one thickening and two rings. We ob- served several well developed live specimens (Figs 12-15). The other three new Trachelomonas taxa are ornamented by variously developed spines. One of them, Trachelomonas thailandicus, is documented by a SEM image (Fig. 20) showing a lorica type not known previously. Trachelomonas paucispinosa sp. nova was observed several times and we also documented a live specimen (Fig. 22). Our specimens were reported earlier from Malaysia (Prowse 1958; Yamagishi 2010) but as T. hystrix var. paucispinosa. In view of the large differences between the putative variety and the type, we reclassified it as a separate taxon. This taxon is one of a group of taxa connected with the tropical zone, such as the newly described $S$. chiangmaiensis. Trachelomonas reticulate-spinifera presents very interesting lorica structure: its wall is reticulate and densely covered with short sharp spines. It is an example of a mixed pattern of lorica development combining the simplest pattern, observed in $T$. reticulate, with the more complicated pattern observed in $T$. hispida, forming a mature lorica with spinney ornamentation.

ACKNOWLEDGEMENTS. We are especially grateful to Associate Professor Yuwadee Peerapornpisal for her help and consultations. We thank our many colleagues for their assistance, and the Applied Algal Research Laboratory, Department of Biology, Faculty of Science, Chiang Mai University, Thailand, for making its database available and for providing access to equipment. We thank Anna Łatkiewicz for help with SEM studies and Michael Jacobs for improving the English version of this work and Professor Pertti Eloranta for valuable remarks on the manuscript. This study was supported by the Royal Golden Jubilee Ph.D. Program of Thailand and through the statutory fund of the W. Szafer Institute of Botany, Polish Academy of Sciences.

\section{REFERENCES}

Bozzola J. J. \& Russell L. D. 1991. Electron microscopy. Principles and technique for biologists. Jones \& Bartlett Publishers, Boston.

Brosnan S., Shin W., KJer K. M. \& Triemer R. E. 2003. Phylogeny of the photosynthetic euglenophytes inferred from the nuclear SSU and partial LSU rDNA. International Journal of Systematic and Evolutionary Microbiology $\mathbf{5 3}$ : 1175-1186. 
Brosnan S., Brown P. J. P., FARmer M. A. \& Triemer R. E. 2005. Morphological separation of the euglenoid genera Trachelomonas and Strombomonas (Euglenophyta) based on lorica development and posterior strip reduction. Phycologia 41: 590-605.

Ciugulea I. \& Triemer R. E. 2010. A color atlas of photosynthetic euglenoids, Michigan State University Press, East Lansing.

Ciugulea I., Nudelman M. A., Brosnan S. \& Triemer R. E. 2008. Phylogeny of the euglenoid loricate genera Trachelomonas and Strombomonas (Euglenophyta) inferred from nuclear SSU and LSU rDNA. J. Phycol. 44(2): 406-418.

CONFORTI V. 1999. Floristic and ultrastructural study of the genus Strombomonas (Euglenophyta) from New Jersey fresh waters. Algol. Stud. 132: 1-20.

CONFORTI V. \& PEREZ M. C. 2000. Euglenophyceae of Negero River, Uruguay, South America. Algol. Stud. 97: 59-78.

CONFORTI V. \& TEll G. 1986. Ultrastructura de la loriga de Trachelomonas Defl. (Euglenophyta) en Microscopio electronico de barridio MEB. Nova Hedwigia 43(1-2): 45-79.

CONRAD W. 1932. Flagellates nouveaux ou peu connu III. Formes nouvelles du genre Trachelomonas E. Arch. Protistenk. 78: 463-472.

DA K. P., MASCAREll G. \& CoUTÉ A. 2009. Étude au microscope électreonicque à balayage du genera Trachelomonas (Euglenophyta) dans le Sud-Est de la Côte d'Ivoire (Afrique) de l'Ouest). Cryptog. Algol. 30(1): 31-90.

DEFLANDRE G. 1926. Monographie du genre Trachelomonas Ehr. Nemours, Paris.

DEFLANDRE G. 1930. Strombomonas nouveau genre d'euglénacées (Trachelomonas Ehr. Pro parte). Arch. Protistenk. 69: $551-61$.

DuAngJan K., Wolowski K. \& PeERAPORnPISAL Y. 2012. A taxonomic and ultrastructural study of Trachelomonas spp. (Euglenophyta) from agricultural area pond, Lamphun Province. Journal of Microscopy Society of Thailand 5(1-2): 23-27.

Dunlap J. R., Walne P. L. \& Bentley J. 1983. Microarchitecture and elemental spatial segregation of envelopes of Trachelomonas lefevrei (Euglenophyceae). Protoplasma 117: 97-106.

DunlaP J. R. \& WALNE P. L. 1985. Fine structure and biomineralization of the mucilage envelopes of Trachelomonas Lefevrei (Euglenophyceae). J. Protozool. 32: 437-441.

Dunlap J. R., Walne P. L. \& KiVIC P. A. 1986. Cytological and taxonomic studies of the Euglenales. II. Comparative microarchitecture and cytochemistry of envelopes of Strombomonas and Trachelomonas. Brit. Phycol. J. 21: 399-405.

EHRENBERG C. G. 1833. Dritter Beitrag zur Erkenntnis großer Organisation in der Richtung des kleinsten Raumes.
Physikalische Abhandlungen der Königlichen Akademie der Wissenschaften zu Berlin 145: 145-336.

Greenberg A. E., Clesceri L. S. \& Eaton A. D. 2005. Standard Methods for Examination of Water and Waste Water. $20^{\text {th }}$ edition. American Public Health Association (APHA), Washington DC.

Huber-Pestalozzi G. 1955. Das Phytoplankton des Süßwassers. In: A. THIENEMANN, Die Binnengewässer. 16(4): 1-606. Euglenophyceen. E. Schweizerbart'sche Verlagsbuchhandlung, Stuttgart.

Lemmermann E. 1913. Eugleninae. In: A. PAscher \& E. LeMMERMANN (eds), Die süsswasserflora Deutschlands, Österreichs und der Schweiz, pp.115-117. G. Fischer. Jena.

LEWMANOMONT K., WONGRAT L. \& SuPANWANID C. 1995. Algae in Thailand - Integrated Promotion Technology Co., Ltd., Thailand.

LIDALE G. F. 1975. Envelope formation and structure in the euglenoid genus Trachelomonas. Brit. Phycol. J. 10: $17-41$.

LinTON E. W., KARNKOWSKA-ISHIKAWA A., KIM J.-I., SHIN W., BenNetT M., KWIATOWSKi J., ZAKRYŚ B. \& TRIEMER E. R. 2010. Reconstructing Euglenoid Evolutionary Relationships using Three Genes: Nuclear SSU and LSU, and Chloroplast $16 \mathrm{~S}$ rDNA Sequences and the description of Euglenaria gen. nov. (Euglenophyta). Protist 161: 603-619.

MERESCHKOWSKY K. S. 1877. Etyudy nad prostejshimi zhivotnymi severa Rosii. Trudy St. Petersburgskogo Obschestva Estestv. 8(2): 1-299.

Peerapornpisal S. Y, Chaiubol C. \& Kriabut H. 2004. The monitoring of water quality in Ang Kaew reservoir of Chiang Mai University by using phytoplankton as bioindicator from 1995-2002. Chiang Mai Journal of Science. 31: 85-94.

Playfair G. J. 1915. The genus Trachelomonas. Proc. Linn. Soc. New South Wales 40: 1-41.

Popova T. G. \& SAFOnOVA T. A. 1976. Euglenophyta. In: M. M. GOLERBACH, Flora plantarum cryptogamarum URSS. 9. Euglenophyta. 2: 352-385. Izdatel'stvo Nauka, Leningrad (in Russian).

PRINGSHEIM E. G. 1953. Observations on same species of Trachelomonas grown in culture. New Phytol. 52: 229-265.

Prowse G. A. 1958. The Eugleninae of Malaya. The Gardens' Bulletin Singapore. XVI: 136-204.

SINGH K. P. 1956. Studies In the genus Trachelomonas. 1. Description of six organisms In Cultivation. Amer. J. Bot. 43: 258-266.

SkVORTZOV B. V. 1917. Materialy po Flagellata Mandžurii I. Zhurn. Mikrobiol. 4: 1-2.

StARMACH K. 1983. Euglenophyta - Eugleniny. Flora Słodkowodna Polski. 3. Państwowe Wydawnictwo Naukowe, Warszawa. 
STEIN F. R. 1878. Der Organismus der Infusionsthiere. III. Der Organismus der Flagellaten, I. Verlag von Wilhelm Engelmann, Leipzig.

West L. K., WALnE P. L. \& BeNTLEY J. 1980. Trachelomonas hispida var. coronata (Euglenophyceae). III. Envelope elemental composition and mineralization. J. Phycol. 16: 582-591.

WOŁOWSKI K. \& HINDÁK F. 2004. Taxonomic and ultrastructural studies of Trachelomonas Ehrenb. emend Deflandre (Euglenophyta) from Slovakia. Nova Hedwigia 78(1): 179-207.
WOŁOWSKI K. \& HINDÁK F. 2005. Atlas of Euglenophytes. VEDA, Bratislava.

WoŁowsKi K. \& WALNE P. L. 2007. Strombomonas and Trachelomonas species (Euglenophyta) from south-eastern U.S.A. Eur. J. Phycol. 42(4): 411-433.

YAMAGISHI T. 2007. Encyclopedia genera of freshwater algae. Uchuda Rokakuho Publishing Co. LTD, Tokyo.

YAMAGISHI T. 2010. Plankton algae of Southeast Asia. Bishan Singh Mahendra pal Singh, India.

Received 18 May 2013 